\title{
STUDY REGARDING CHANGES IN DECISION-MAKING PROCESS DURING THE CRISIS PERIOD
}

\author{
Diana RANF \\ ranfd@yahoo.com \\ Hortensia GORSKI \\ tenzig11@yahoo.com
}

“NICOLAE BĂLCESCU” LAND FORCES ACADEMY, SIBIU, ROMANIA

\begin{abstract}
Why the decision? Because we have to make decisions every day, more important or less important decisions that lead our lives in a certain direction, in both cases being necessary to choose between several courses of action. The decision is part of our lives and making the optimal decision is important, whether it comes from managers or from regular individuals. An organizational environment characterized by insecurity, frequent and sudden changes has a negative impact on the management of an organization. Under these circumstances, the reaction to these changes, instabilities materialize in quick, correct decisions that induce organizational stability. The main objective of the article is to analyze the decision-making process within the organizations that constitute the private environment in Sibiu. The question that the article wants to answer is: the expertise (knowledge, theories, methods) of managers in decision making sufficient or does this new context require an adaptation, reorganization of the decision-making process? The article contains a qualitative interview-based investigation, which is the premise of a comprehensive research based on a questionnaire to provide solutions to the problems identified.
\end{abstract}

\section{Keywords:}

Decisions, management, decision maker, methods

\section{Introduction}

The current economic and social context in which we operate, characterized by instability in all areas creates new requirements in terms of adaptability to work, speed and correctness of decisions taken. The pandemic crisis generated by the
Covid virus has amplified and developed globally other types of crises, among which a major one is beginning to stand out, namely the economic crisis.

A research conducted between March 28 and April 4, 2020 has concluded that the pandemic had already caused massive 
dislocation among small businesses from USA just several weeks after its onset (Bartik, 2020).

Thus, the focus is on finding solutions and even improving the management system, so that it meets the need in practice. An important element of the management process is the decision-making system, which is also the object of study of this article.

The decision is an essential element of management being one of the most important specific tools of expression. The whole managerial process focuses on the elaboration, adoption and application of some decisions (Gorski, 2008).

There are opinions according to which our decisions, our choices, regardless of their complexity, also depend on the way our mind works and offers solutions to the problems we face (Ungureanu, 2018).

The entire activity of a manager can be defined as a chain of decisions, specifying that their effectiveness depends on the extent to which their development is scientifically substantiated, taking into account as many factors as possible that condition their implementation into practice. Hence the need for a full understanding of the entire decision-making process (Ranf, 2014).

The distinction made by the authors between the notions of choice and decision, in the sense that the choice is intuitive, instinctive or even spontaneous, while the decision requires a preliminary and thorough analysis, is no longer respected, meaning that most current decisions require short reaction time and receive the character of spontaneity (Dobre, Bădescu \& Păuna, 2007).

Managers develop and make many different decisions during their work. While managers at the lower levels of the organization carry out activities that do not materialize in "monumental" or extraordinary decisions, they have to deal with many actions that involve the development and decision-making of insignificant, less important decisions, but which have a cumulative effect on organizational effectiveness. That is why we consider that a deep knowledge and the application adapted to the situation of the models of managerial decisions are of vital importance for the organization (Lixăndroiu, 2014).

There are studies that identified eight crisis decision-making concepts: meaning of decision, meaning of the crisis decisionmaking process, stages of the crisis decision-making process, crisis decisionmaking's response; crisis management; crisis decision-making strategies, decisionmaking skills; the role of decision-maker in crisis (Zeyad, 2020).

\section{Methodological aspects}

The research is an original contribution to the existing amount of knowledge aimed at enriching it; it is the search for truth, using study, observation, comparison and experiment. In short, the search for knowledge through objective and systematic methods to identify solutions to a problem is research (Rajendra, 2008).

The analysis carried out in the article contains a qualitative exploratory research and had several purposes: identifying the problems encountered by managers in the decision-making process, the methods on which decision-making is based within the organizations they manage, the degree of consultation with employees in decision making.

It is known that in exploratory research, the creativity and skills of the researcher play an important role.

In addition, the researcher can use various methods: analysis of secondary data; interviews conducted among experts; (focused) group meetings; case studies; pilot studies (Cătoiu, 2009). In the research carried out, the following methods were used:

- Secondary data analysis. Secondary data analysis is a fast and less expensive method, which involves capitalizing on available data from various 
sources. Their analysis aimed to identify information on the type of organizations, the position on the market.

- Interviews conducted among experts. These aimed at obtaining information from specialists in implementing decisions within institutions in times of crisis. In this context, a small sample (10 individuals) was used, who were selected based on their experience in the field.

Qualitative and quantitative research methods are used in combination, this approach being required mainly due to the very complex reality, whose truths cannot be captured by using a single method. However, the investigation has a pronounced quantitative character, the role of qualitative research being to provide the premises for carrying out the quantitative research.

The investigation begins with a qualitative research based on an interview meant to allow the researcher to get acquainted with the problems of the subjects related to the topic of the investigation, with the causes that generated problems in decision making. This preliminary investigation of the questionnaire-based research aims to provide information to help the researcher to prepare the questionnaire, so that the questions allow obtaining as comprehensive information as possible that will help to solve the identified problems.

\section{Deficiencies in the crisis decision-making process}

The main purpose of the interviews was:

- Familiarization of the researcher with the studied problem and with the targeted activity sector. In this case, the main problems encountered in the decisionmaking process by managers of the business environment in Sibiu, as well as with representatives of public institutions were identified. For this purpose, interviews were conducted with decision makers (general manager or functional managers) within the institutions;

- Identifying the attitude and motivations of business representatives in relation to Covid crisis management;

- Refutation or confirmation of certain hypotheses;

- Understanding the decisionmaking behavior of respondents underlying decisions on accessing policy support tools for overcoming the crisis caused by the Covid pandemic.

The interviews conducted among the experts aimed at obtaining information from specialists regarding the decisionmaking process within the institutions. In this context, a small sample (10 individuals) was used, who were selected based on experience in the field or position in the institution (decision makers).

Table no. 1

Identification data of the respondents and the institutions they represent

\begin{tabular}{|c|c|c|c|c|c|}
\hline & $\begin{array}{c}\text { Commercial } \\
\text { company }\end{array}$ & $\begin{array}{c}\text { Commercial } \\
\text { company }\end{array}$ & $\begin{array}{c}\text { Local public } \\
\text { administration }\end{array}$ & NGO & $\begin{array}{c}\text { Public } \\
\text { institutions }\end{array}$ \\
\hline $\begin{array}{l}\text { Number of } \\
\text { employees }\end{array}$ & over 250 & $10-49$ & $10-49$ & $\begin{array}{l}\text { less than } 9 \\
\text { employees }\end{array}$ & $10-49$ \\
\hline Form of capital & public & private & public & private & public \\
\hline $\begin{array}{l}\text { Age of the } \\
\text { institution }\end{array}$ & over 12 years & over 5 years & over 12 years & $\begin{array}{l}\text { over } \\
5 \text { years }\end{array}$ & $\begin{array}{c}\text { over } \\
12 \text { years }\end{array}$ \\
\hline $\begin{array}{l}\text { Respondents' } \\
\text { seniority in } \\
\text { management } \\
\text { positions }\end{array}$ & 3 years & 5 years & 10 years & 7 years & 3 years \\
\hline
\end{tabular}


Table no. 1 contains information on the institutions from which the respondents come. Although the sample is small, the institutions represented by the investigated persons cover a wide spectrum in terms of their characteristics, namely: a state-owned company subordinated to the Local Council of Sibiu, a local public administration, a non-governmental organization two public institutions and five managers from the Sibiu private environment.

Following the interviews with representatives of the institutions, the following conclusions were drawn:

- The problems encountered by the institutions in making decisions regarding the management of the employees' work schedule as a result of the need for the restrictions generated by the Covid crisis (Figure no. 1);

- Subordinates are only occasionally consulted in the decision-making process;

- Decision-making techniques are little known among respondents, they are based on decision-making mainly on experience and intuition;
- Management decisions and actions, and especially the way they have been implemented in the last period, have generated dissatisfaction among subordinates, which has led to tensions in activities, decreased productivity in certain areas or inappropriate behaviors;

- The general context created by the pandemic facing humanity has led to a decrease in internal communication, at the organizational level or with the external environment, which can lead to a decrease in response capacity depending on the type of organization and how each would you have to relate to the situation, as follows:

- Institutions with public administration status have the role of managing the period, meeting the difficulties of the private environment with quick, correct and feasible solutions;

- The private environment must make the best decisions in the short term so as not to affect the long-term development of the organization and ensure the safety of employees.

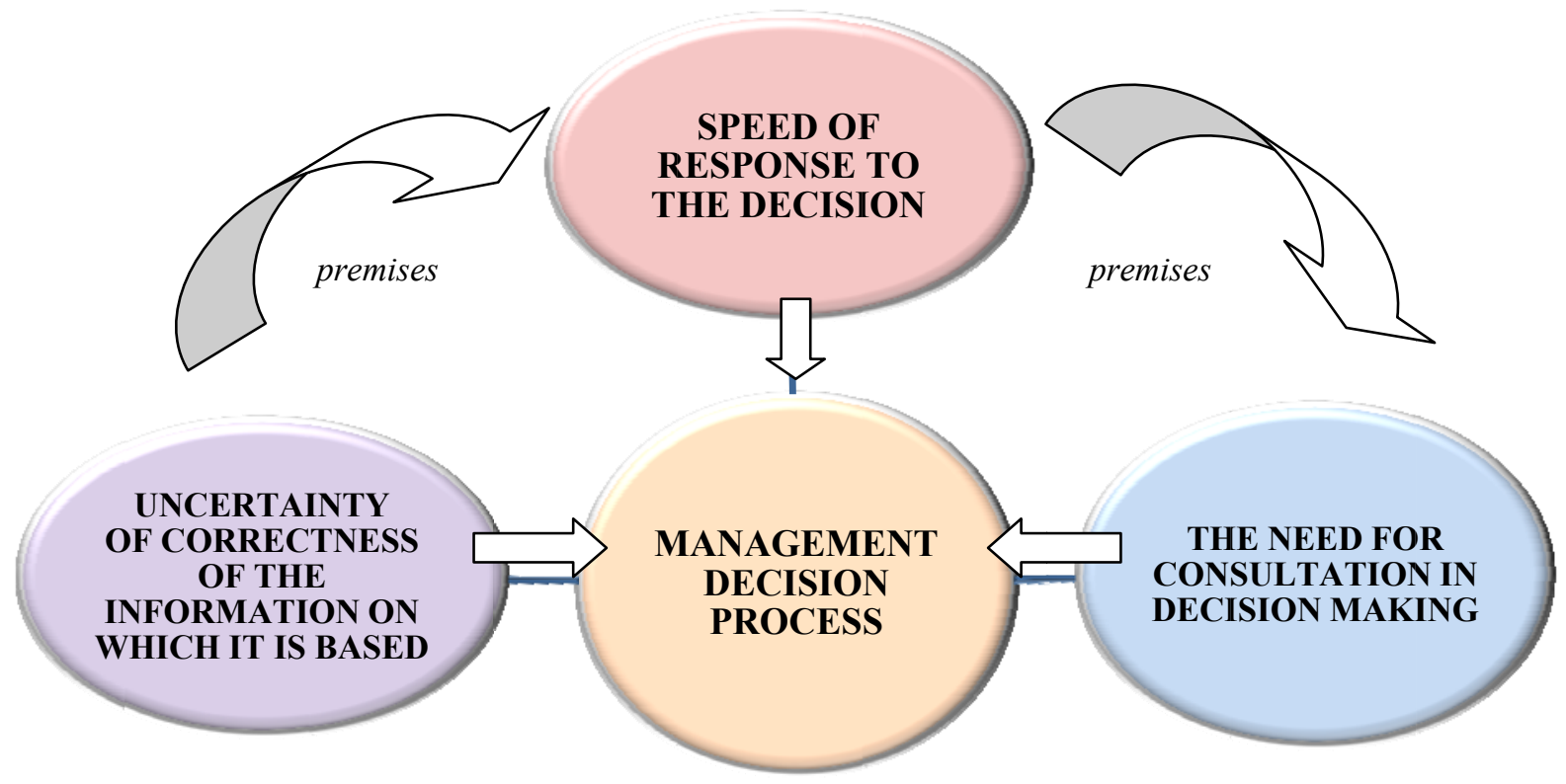

Figure no. 1: Causes of the problems encountered by the organizations under investigation in decision making

(Source: Authors) 
Figure no. 1 concludes the study, pointing out the premises on which most of the problems encountered by organization managers in decision making are based. The sudden changes dictated by various directives (emergency ordinances) or recommendations of the institutions that generate the pandemic at national level have created new requirements for decisions. One of the most important requirements is the speed of reaction, the speed of making a decision that can affect the long-term organization, the professional and personal lives of employees, their health and safety.

If the interviews resulted in a very fragile consultation of subordinates in decision making, perhaps in these conditions, where stress and insecurity focus on managers and key decision makers in organizations, responsibility should be shared. Thus, a decision in which the subordinate was consulted can be more easily accepted, even if it produces negative effects on him/her.

Perhaps the most important factor that negatively influences the decision-making process in organizations is that the information on which it bases its decision may change even before that decision is put into practice. This can lead in time to the loss of its credibility among subordinates.

\section{Conclusions}

The research, whose target group is represented by the managers of the institutions from Sibiu County, aims at obtaining information from the respondents regarding: the type of problems encountered in the decision-making process; the importance they give to decision-making techniques and the degree to which they use them.

The method used to obtain the information is qualitative exploratory research based on an interview, research in which 10 managers of public and private institutions from Sibiu County participated.

The main information revealed a number of problems that managers face in the decision-making process, such as: insecurity in decision-making, lack of risktaking during this period, complaints from subordinates about the lack of communication in decision-making. These aspects create the premises for a questionnaire-based research, able to identify the main causes of the problems and to offer solutions to improve the decision-making process.

The managerial decision has also undergone changes in terms of implementation requirements. Flexibility in decision-making, adaptation to change, changing rules and consultation should be new rules to guide the decision-making process.

The health and economic crisis generated by the Covid pandemic has created the context of changes that must be adopted in both the theory and practice of management, and the decision-making process must be at the heart of experts' analysis, because decisions taken and implemented during this period can affect not only the subjects directly involved now, but also future generations. 


\section{REFERENCES}

Bartik, A. W., Bertrand, M., Cullen, Z., Glaeser, E. L., Luca, M., \& Stanton, C. (2020). The impact of COVID-19 on small business outcomes and expectations. Proceedings of the National Academic of Sciences, available at: https://doi.org/10.1073/pnas.2006991117, accessed on 20 October 2020;

Cătoiu, I. (2009). Cercetări de marketing. Bucharest: Uranus Publishing.

Dobre, I, Bădescu, A. V., \& Păuna, L. (2007). Teoria deciziei. Bucharest: ASE Publishing.

Gorski, H. (2008). Management - Elemente fundamentale. Sibiu: Editura Universităţii "Lucian Blaga".

Lixăndroiu, D. (2014). Modelarea deciziei economice. Bucharest: Editura Economică.

Rajendra, K. (2008). Research Methodology. India: APH Publishing Corporation.

Ranf, D.E. (2014). Managementul proiectelor cu finanțare europeană. Sibiu: Editura Universităţii "Lucian Blaga".

Ungureanu, M. (2018). Economia și psihologia deciziei. Introducere în economia comportamentală. Iași: Editura Institutul European.

Zeyad, S. Al-Dabbagh. (2020). The Role of Decision-maker in Crisis Management: A qualitative Study Using Grounded Theory (COVID-19 Pandemic Crisis as A Model). Wiley Academic Paper, available at: https://doi.org/10.1002/pa.2186, accessed on 20 October 2020 . 